$$
\begin{array}{ll}
\text { DOSENPENGAMPUH } & \text { : JUSMAWATI, S.Pd,M.Pd } \\
\text { MATAKULIAH } & \text { : PENDIDIKAN MATEMATIKAII }
\end{array}
$$

\title{
PENDIDIKAN MATEMATIKA II
}

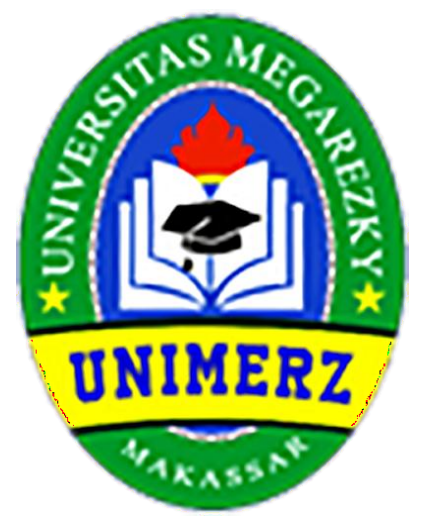

DISUSUN OLEH

MARJUNI. L ( C1C119007)

PENDIDIKAN GURU SEKOLAH DASAR

FAKULTAS KEGURUAN DAN ILMU PENDIDIKAN UNIVERSITAS MEGAREZKY

2022 


\section{KATA PENGANTAR}

Puji Syukur senantiasa kami panjatkan kehadirat Tuhan Yang Maha Esa yang telah melimpahkan rahmat dan karunia-nya, sehingga kami dapat menyelesaikan makalah ini guna memenuhi tugas kelompok untuk mata kuliah Pendidikan Matematika II, dengan judul : "PENDIDIKAN MATEMATIKA II"

Kami menyadari bahwa dalam penulisan makalah ini tidak terlepas dari bantuan banyak pihak yang dengan tulus memberikan doa, saran dan kritik sehingga maklah ini dapat terselesaikan.

Kami menyadari sepenuhnya bahwa makalah ini masih jauh dari sempurna dikarenakan terbatasnya pengalaman dan pengetahuan yang kami miliki. Oleh karena itu, kami mengharapkan segala bentuk saran serta masukan bahkan kritik yang membangun dari berbagai pihak. Akhirnya kami berharap semoga makalah ini dapat memberikan manfaat bagi perkembangan dunia pendidikan.

Penyusun

penulis 
DAFTAR ISI

KATAPENGANTAR _ _ _ _ _ _ _ _ _ _ _ _ _ _ _ _ _ _ _ _ _ _

$\mathrm{BABI}$

PENDAHULUAN _ _ _ - 1

A. Latar Belakang _ _ 1

B. RumusanMasalah 1

C. Tujuan _ 2

$\mathrm{BAB} I \mathrm{~L}$

PEMBAHASAN

A. Desimal _ 3

B. Bangun Datar Segitiga 4

C. Bangun Ruang Limas Segilima _. 5

BABIII 13

PENUTUP 13

A. Kesimpulan 13

B. Saran 13

DAFTARPUSTAKA...__ 14 
BAB I

\section{PENDAHULUAN}

\section{A. Latar Belakang}

Matematika merupakan suatu ilmu yang berhubungan dengan penelaahan bentuk-bentuk atau struktur- struktur yang abstrak dan hubungan-hubungannya diantara hal-hal itu. Bertitik tolak dari tujuan pembelajaran matematika di Sekolah Dasar yaitu menumbuhkan dan mengembangkan keterampilan berhitung sebagai alat dalam kehidupan sehahari-hari, maka matematika sebagai salah satu ilmu dasar yang memberi tekanan pada penalaran dan pembentukan sikap anak memberikan pengajaran decimal dalam menerapakan matematika dalam kehidupanseharihari.

Konsep dasar matematika harus betul-betul ditanamkan pada diri pribadi siswa sekolah dasar. Karena jika penguasaan mereka terhadap konsep matematika dalam hal ini mengenai Desimal pada Sekolah Dasar sekarang tentu akan menjadi faktor kesulitan bagi siswa ketika melanjutkanpendidikan.

B. RumusanMasalah

Berdasarkan latar belakang tersebut kami merumuskan beberapa masalah yaitu diantaranya :

1. Apa itu desimal?

2. Bagaimana Mengubah Pecahan Desimal Menjadi pecahan Biasa?

3. Cara Penjumlahan Dan Pengurangan Desimal?

4. Bagaimana Mengubah pecahan kebentuk desimal dansebaliknya

5. Bagaimana cara PembulatanDesimal?

6. Apa itu Bangun Datar Segitiga 
7. Apa Itu Bangun Ruang Limas Segilima

C. Tujuan

1. Mengetahui pengertiandecimal

2. Memahami cara mengubah pecahan desiman menjadi pecahanbiasa

3. Mengetahui penjumlahan dan pengurangandecimal

4. Memahami cara mengubah pecahan decimal dan sebaliknya mengetahui cara pembulatandecimal

5. Mengetahui pengertian Bangun Datar Segitiga

6. Mengetahui jenis-jenis dan Rumus Segitiga

7. Mengetahui apa itu Bagun Ruang Limas Segilima

8. Mengetahui Rumus dan Volume Limas Segilima 


\section{BAB II}

\section{PEMBAHASAN}

\section{A. Desimal}

Desimal adalah bilangan yang memuat tanda koma(,) sebagai pemisah antara bilangan bulat dengan bilangan pecahan. misalnya 0,3;0,25;4,753;34,47; dan sebagainya. Bilangan juga merupakan bilangan berbasis sepuluh atau dapat diartikan sebagai penyebut bilangan persepuluh, perseratus,perseribu, dan seterusnya.

Bilangan desimal adalah bilangan yang terdiri dari bilangan bulat dan bilangan pecahan, yang dalam penulisannya antara bilangan bulat dan pecahan dipisahkan dengan tanda koma, yang disebut

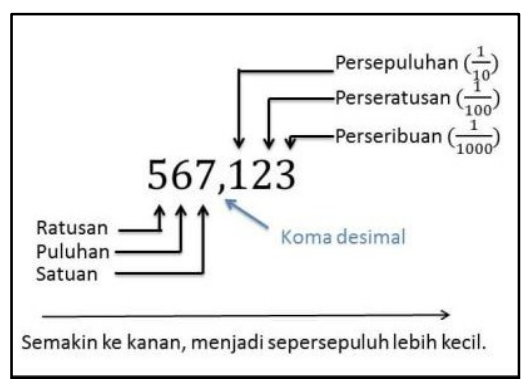
dengan komadesimal.

Dari tiga materi pelajaran matematika yang diajarkan di Sekolah Dasar (aritmatika, aljabar, dan geometri), materi aljabar khususnya pecahan desimal sering menjadi penyebab rendahnya prestasi belajar matematika siswa Sekolah Dasar dan bahkan siswa Sekolah Menengah. Untuk mempelajari konsep pecahan desimal, dapat dimulai dengan memahami konsep pecahan persepuluhan, perseratusan, danperseribuan.

Pecahan desimal adalah pecahan yang mempunyai penyebut khusus, yaitu sepuluh, seratus, seribu, dan seterusnya. Untuk penyebut persepuluhan, di belakang koma ada 1 angka yang merupakan angka pembilang.

Rumus bilangan decimal dalam oprasi penjumblahan dapat dilakukan seperti contoh berikut

1. $0,3+0,5===0,8--$ 
Cara mengubah pecahan biasa ke bentuk

desimal. Contoh :

Ubah pecahan beriut menjadi pecahan desimal

1. -

Jawab:

$$
\begin{aligned}
& \frac{0,6}{3} \\
& \frac{0}{30}- \\
& \frac{30}{0}-
\end{aligned}
$$

Jadi, $\frac{3}{5}=0,6$.
$2 .=$

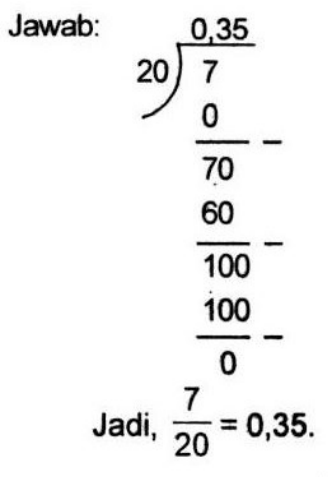

Pecahan-pecahan yang penyebutnya $10,100,1000$. dan seterusnya dapat dinyatakan dengan mudah sebagai pecahan decimal.

contoh :
1. -()
()
$2-()$
4. -()

1. Mengubah Pecahan Desimal Menjadi pecahan Biasa 
Untuk pecahan-pecahan yang penyebutnya bukan bilangan 10 atau kelipatan 10 , yang harus dilakukan terlebih dahulu adalah mengubah penyebutnya menjadi bilangan 10 atau kelipatannya.

Contoh :

1. $0,15=--$

2. $0,75=--$

3. $0,125=\square-$

Perhatikan tabel berikut!

\begin{tabular}{|c|c|c|}
\hline No. & Pecahan Desimal & Pecahan Biasa \\
\hline 1. & 0,07 & - \\
\hline 2. & 0,45 & - \\
\hline 3. & 3,5 & - \\
\hline 4. & 32,54 & - \\
\hline 5. & 15,42 & \\
\hline
\end{tabular}

2. Penjumlahan Dan PenguranganDesimal

1. Penjumlahan dan pengurangan pecahan Desimal 
Dalan menjumlahkan pecahan decimal dengan cara bersusun perlu diperhatikan bahwa tanda koma diletakkan sejajar.

Contoh :

$1.2,3447+6,735=\ldots$.

Jawab :

11

2,347

$\mp$

Jadi $2,347+6,735=9,082$

2. $43,732+8,947+123,34=$

Jawa

b:

43,73

2

8,947

$3.28,23-12,13$

Jawab:

$4.34,1-9,9$

3. Mengubah pecahan kebentuk decimal dansebaliknya

2. Mengubah pecahan kebentukdecimal

Untuk mengubah pecahan biasa menjadi bilangan desimal dapat dilakukan dengan cari berikut ini. Untuk pecahan-pecahan yang penyebutnya bilangan 10 atau kelipatan dari 10 dapat 
diubah langsung di mana banyaknya angka desimal yaitu angka di sebelah kanan koma atau titik yang diperoleh sama dengan banyaknya nol pada penyebut.

Misalnya:

ada 2 angka nol pada penyebutnya, maka akan ada 2 angka didepan decimal.

Untuk pecahan-pecahan yang penyebutnya bukan bilangan 10 atau kelipatan 10, yang harus dilakukan terlebih dahulu adalah mengubah penyebutnya menjadi bilangan 10 atau kelipatannya.

a) Menggunakan pecahan sama dengan penyebut kelipatan

10 dan Perhatikan contoh berikutini.

1) Tulislsh bilanganke dalam bentuk pecahandecimal Jawab:

$=$ = $\boldsymbol{x}-$

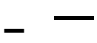

$=0,4$

2) Tuliskan bilangan6 _ kedalam bentuk pecahan decimal Jawab:

$$
\begin{aligned}
& =6=6+- \\
& =6+\ldots \times- \\
& =6+ \\
& =6+0,12
\end{aligned}
$$


$=6,12$

3) Tuliskanbilangan — kedalam bentuk pecahan decimal 
Jawab:

$$
\begin{aligned}
& -\overline{-} \\
& -\quad- \\
& =0,5
\end{aligned}
$$

4) Tuliskan bilangan desimal 0,52 kedalam bentukpecahan

$=0,52$ adalah $*-$

Penjelasan:

Bilangan decimal ini mempunyai dua angka dibelakang koma ,artinya perseratus.

5) Tuliskan bilangan desimal 0,954 kedalam bentukpecahan

$=0,954$ adalah $x$

Bilangan decimal ini mempunyai tiga angka dibelakang koma artinya perseribu

b) Untukmengubah decimal

kepecahan,ikutilangkah-

langkahini:Langkah1:Susunkebawahbilangan

decimal

yangdapatdibagidengan1.Langkah2:Kalikanpenyebutdanpembila ngden

gan10untuksetiapangkadibelakangkomadesimal.(Misalnya,jikat erdapat duaangkadibelakangkoma decimal makakalikan100,jikatigaangkakalikan1.000,dst.)Langkah3:Seder hanak an(ataukecilkan)pecahan.

4. PembulatanDesimal

Pembulatan desimal meliputi pembulatan kesatuan terdekat,pembulatan kepuluhan terdekat,pembulatan keratusan terdekat, dan selanjutnya.

a.pembulatan kesatuan terdekat,contohnya 
1. 1,6 dibulatkan kesatuan terdekat menjadi2.

2. 16,234 dibulatkan kesatuan terdekat menjadi16.

b. pembulatan kepuluhan terde3kat,contohnya

1. 125 dibulatkan kepuluhan terdekat menjadi130

2. 1032 dibulatkan kepuluhan terdekat menjadi1030

c. pembulatan keratusan terdekat,contohnya

1. 1728 dibulatkan keratusan terdekat menjadi1700

2. 287 dibulatkan keratusan terdekat menjadi300

\section{Pecahan Desimal TakTerbatas}

Pecahan decimal tak terbatas dalah pecahan desimal dengan jumlah digit yang tak terbatas.Jelas bahwa kita tidak dapat menulis pecahan desimal tak terhingga secara penuh, oleh karena itu, dalam pencatatannya, kita dibatasi hanya pada jumlah digit tertentu setelah koma desimal dan meletakkan elipsis, yang menunjukkan urutan digit yang terus berlanjut tanpa batas. Berikut adalah beberapa contoh pecahan desimal tak hingga: 0.143940932 ..., $3.1415935432 \ldots, 153.02003004005 \ldots, 2.111111111 \ldots$, $69.74152152152 \ldots$.

Jika Anda melihat lebih dekat pada dua pecahan desimal tak hingga terakhir, maka dalam pecahan 2.111111111 ... angka 1 yang berulang tanpa batas terlihat jelas, dan dalam pecahan 69.74152152152 ..., mulai dari tempat desimal ketiga, kelompok angka 1, 5, dan 2 yang berulang terlihat jelas. Pecahan desimal tak terhingga seperti itu disebut periodik

a. Pecahan desimal berkala (atau sederhananya pecahan periodik) Adalah pecahan desimal tak terhingga, yang notasinya, dimulai daribeberapa 
tempat desimal, beberapa digit atau sekelompok digit diulangi tak terhingga, yang disebut periode pecahan.

Misalnya, periode pecahan periodik 2.111111111 ... adalah angka 1, dan periode pecahan 69.74152152152 ... adalah sekelompok angka seperti 152.

Untuk pecahan desimal periodik tak terbatas, digunakan notasi khusus. Untuk singkatnya, kami setuju untuk menulis titik satu kali, mengisinya dengan tanda kurung. Sebagai contoh, pecahan periodik $2.111111111 \ldots$ ditulis 2, (1), dan pecahan periodik $69.74152152152 \ldots$ ditulis 69.74 (152).

Perlu dicatat bahwa periode yang berbeda dapat ditentukan untuk pecahan desimal periodik yang sama. Misalnya, pecahan desimal periodik $0,73333 \ldots$ dapat dipandang sebagai pecahan 0,7 (3) dengan periode 3 , serta pecahan 0,7 (33) dengan periode 33 , dan

seterusnya 0,7 (333), 0,7 (3333), ... Anda juga dapat melihatpecahan

periodik 0.73333 ... seperti ini: 0.733 (3), atau lebih 0.73 (333), dll. Di sini, untuk menghindari ambiguitas dan perbedaan, kami setuju untuk mempertimbangkan urutan terpendek dari semua kemungkinan angka berulang, dan mulai dari posisi terdekat ke titik desimal, sebagai periode pecahan desimal. Artinya, periode pecahan desimal 0,73333 ... akan dianggap sebagai urutan satu digit 3, dan frekuensi dimulai dari posisi kedua setelah titik desimal, yaitu 0,73333 ... \u003d 0,7 (3). Contoh lain: pecahan periodik $4.7412121212 \ldots$ memiliki periode 12 , periodisitas dimulai dari digit ketiga setelah koma, yaitu, 4.7412121212... lu003d 4.74 (12). 
Pecahan periodik desimal tak hingga diperoleh dengan mengubah pecahan biasa menjadi pecahan desimal, yang penyebutnya mengandung faktor prima selain 2 dan 5 .

Di sini perlu disebutkan tentang pecahan periodik dengan periode 9. Berikut adalah contoh pecahan tersebut: 6.43 (9), 27, (9). Pecahan ini adalah notasi lain untuk pecahan periodik dengan periode 0 , dan biasanya diganti dengan pecahan periodik dengan periode 0 . Untuk melakukan ini, periode 9 diganti dengan periode 0 , dan nilai pangkat tertinggi berikutnya bertambah satu. Misalnya, pecahan dengan periode 9 seperti 7,24 (9) diganti dengan pecahan periodik dengan periode 0 seperti 7,25 (0) atau pecahan desimal akhir yang sama dengan 7,25. Contoh lain: 4, (9) \u003d 5, (0) \u003d 5. Persamaan pecahan dengan periode 9 dan pecahan yang bersesuaian dengan periode 0 mudah ditentukan setelah mengganti pecahan desimal ini dengan pecahan biasa yangsetara.

Terakhir, mari kita lihat lebih dekat pecahan desimal tak hingga, yang tidak mengandung deretan angka yang berulang tak terhingga. Mereka disebut non-periodik.

b. Desimal non-periodik (atau sederhananya pecahan non-periodik) Apakah pecahan desimal tak terbatas tanpa titik. Terkadang pecahan non periodik memiliki bentuk yang mirip dengan bentuk pecahan periodik, misalnya 8.02002000200002 ... - pecahan non periodik. Dalam kasus ini, Anda harus sangat berhati-hati untuk melihat perbedaannya. 
Perhatikan bahwa pecahan non-periodik tidak dapat diubah menjadi pecahan biasa, pecahan desimal non-periodik tak terhingga mewakili bilangan irasional.

\section{B. Bangun Datar Segitiga}

1. Pengertian Segitiga

Segitiga adalah bangun datar yang dibatasi oleh tiga buah sisi dan mempunyai tiga buah titik sudut.

2. Jenis-jenis Segitiga

Jenis-jenis suatu segitiga dapat ditinjau berdasarkan

> Panjang sisi-sisinya :

- Segitiga sembarang

Segitiga sembarang adalah segitiga yang sisi-sisinya tidak sama panjang.

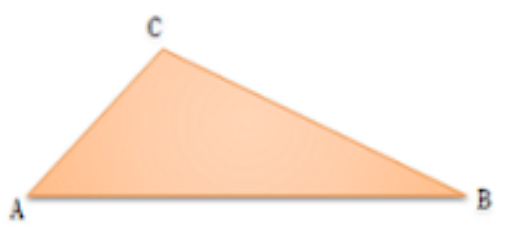

- Segitiga sama kaki

Segitiga sama kaki adalah segitiga yang mempunyai dua buah sisi sama panjang

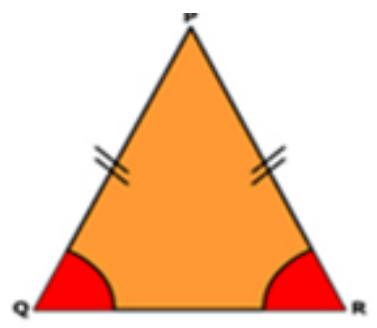


- $\quad$ Segitiga sama sisi

Segitiga sama sisi adalah segitiga yang memiliki tiga buah sisi sama panjang dan tiga buah sudut sama besar.

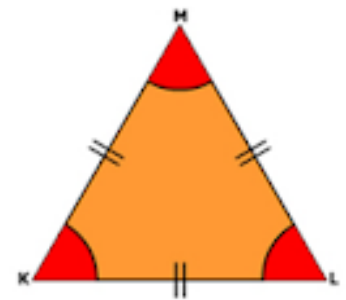

> Besar sudut-sudutnya :

- Segitiga lancip adalah segitiga yang ketiga sudutnya merupakan sudut lancip, sehingga sudut-sudut yang terdapat pada segitiga tersebut besarnya antara 0 o dan 900 .

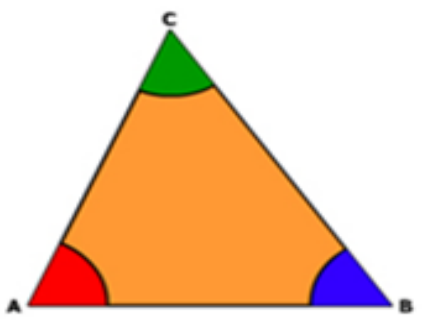

- Segitiga tumpul

Segitiga tumpul adalah segitiga yang salah satu sudutnya merupakan sudut tumpul.

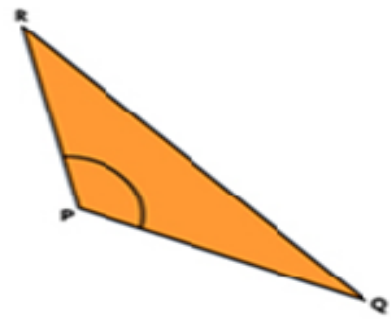

- Segitiga siku-siku 
Segitiga siku-siku adalah segitiga yang salah satu sudutnya merupakan sudut siku-siku (besarnya 90o).

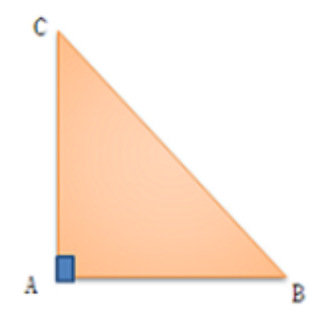

> Panjang sisi dan besar sudutnya :

- Jika pada sebuah segitiga ketiga sudutnya lancip dan panjang ketiga sisinya sama, maka segitiga itu disebut segitiga lancip sama sisi

- Jika pada sebuah segitiga ketiga sudutnya lancip dan panjang dua sisinya sama, maka segitiga itu disebut segitiga lancip sama kaki

- Jika pada sebuah segitiga ketiga sudutnya lancip dan panjang ketiga sisinya berbeda, maka segitiga itu disebut segitiga lancip sembarang

- Jika pada sebuah segitiga salah satu sudutnya tumpul dan ada dua sisi yang sama panjang, maka segitiga itu disebut segitiga tumpul sama kaki

- Jika pada sebuah segitiga salah satu sudutnya tumpul dan panjang ketiga sisinya berbeda, maka segitiga itu disebut segitiga tumpul sembarang

- Jika pada sebuah segitiga salah satu sudutnya siku-siku dan ada dua sisi yang sama panjang, maka segitiga itu disebut segitiga siku-siku sama kaki

- Jika pada sebuah segitiga salah satu sudutnya siku-siku dan panjang ketiga sisinya berbeda, maka segitiga itu disebut segitiga siku-siku sembarang.

> Sifat-Sifat Segitiga Istimewa

- Segitiga siku-siku

Besar salah satu sudut pada segitiga siku-siku adalah 900 
- Segitiga sama kaki

1) Segitiga sama kaki dapat dibentuk dari dua buah segitiga sikusiku yang sama besar dan sebangun.

2) Segitiga sama kaki mempunyai dua buah sisi yang sama panjang dan dua buah sudut yang sama besar.

3) Segitiga sama kaki mempunyai sebuah sumbu simetri.

- Segitiga sama sisi

1) Segitiga sama sisi mempunyai tiga buah sisi yang sama panjang dan tiga buah sudut yang sama besar.

2) Setiap segitiga sama sisi mempunyai tiga sumbu simetri.

Keliling dan luas daerah segitiga

- Keliling Segitiga

keliling segitiga adalah jumlah panjang ketiga sisi yang membentuk jumlahpanjang segitiga.

$K=\operatorname{sisi} 1+\operatorname{sisi} 2+\operatorname{sisi} 3$

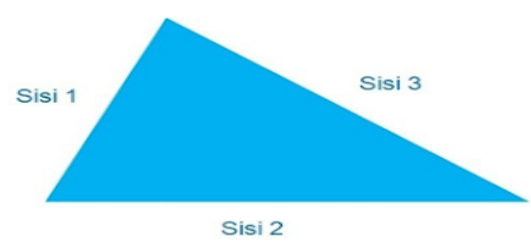

Contoh 1:

Keliling sebuah segitiga $20 \mathrm{dm}$. Jika panjang dua buah sisinya $9 \mathrm{dm}$ dan $6 \mathrm{dm}$, berapakah panjang satu sisi lainnya?

Jawab:

Keliling segitiga adalah $\mathrm{K}=$ Sisi $1+\operatorname{Sisi} 2+\operatorname{Sisi} 3$

$20 \mathrm{dm}=9 \mathrm{dm}+6 \mathrm{dm}+$ Sisi 3

$20 \mathrm{dm}=15 \mathrm{dm}+$ Sisi 3

Sisi $3=20 \mathrm{dm}-15 \mathrm{dm}=5 \mathrm{dm}$

Jadi, panjang satu sisi lainnya tersebut adalah $5 \mathrm{dm}$. 
- Luas segitiga

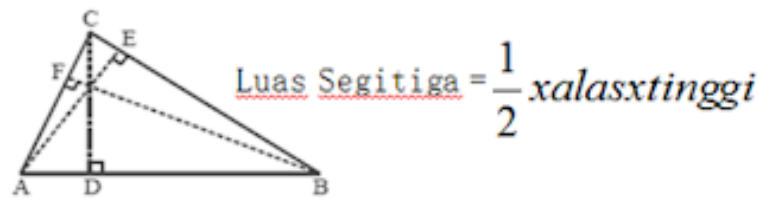

Contoh:

Luas sebuah segitiga $35 \mathrm{~cm} 2$. Jika alasnya $10 \mathrm{~cm}$, coba tentukan tinggi segitiga tersebut.

Jawab:

Luas segitiga tersebut $35 \mathrm{~cm} 2$ dan alasnya $10 \mathrm{~cm}$.

section-media

$\mathrm{t}=7 \mathrm{~cm}$

Dengan demikian, tinggi segitiga tersebut adalah $7 \mathrm{~cm}$

- Melukis Segitiga

$\star$ Melukis Segitiga Apabila Diketahui Panjang Ketiga Sisinya (Sisi, Sisi, Sisi)

Misalkan kita akan melukis segitiga $A B C$ jika diketahui $A B=7 \mathrm{~cm} B C=5 \mathrm{~cm}$, dan $A C=4 \mathrm{~cm}$.

Langkah-langkahnya adalah sebagai berikut:

1) Buatlah ruas garis $A B$ dengan panjang $7 \mathrm{~cm}$.

2) Dengan pusat titik $A$ buatlah busur lingkaran dengan jari-jari $4 \mathrm{~cm}$.

3) Kemudian dengan pusat titik B buatlah busur lingkaran dengan jari-jari 5 cm sehingga memotong busur pertama di titik $\mathrm{C}$.

4) Hubungkan titik $A$ dengan titik $C$ dan titik $B$ dengan titik $C$, sehingga terbentuk segitiga $A B C$

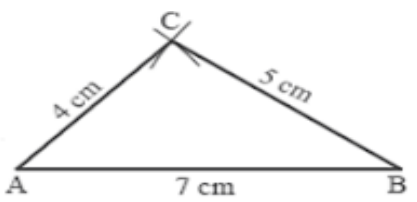


$\star \quad$ Melukis Segitiga jika Diketahui Dua Sisi dan Sudut Apit Kedua Sisi Tersebut (Sisi, Sudut, Sisi)

Misalkan kita akan melukis segitiga KLM jika diketahui panjang $\mathrm{KL}=3 \mathrm{~cm}, \mathrm{LKM}=70 \mathrm{o}$, dan panjang $\mathrm{KM}=4 \mathrm{~cm}$.

Langkah-langkahnya sebagai berikut.

1) Buatlah ruas garis $K L$ dengan panjang $3 \mathrm{~cm}$.

2) Dengan menggunakan busur derajat, pada titik $K$ buatlah sudut yang besarnya 700 .

3) Kemudian dari titik $\mathrm{K}$ buatlah busur lingkaran dengan panjang jari-jari $4 \mathrm{~cm}$, sehingga berpotongan di titik $\mathrm{M}$

4) Hubungkan titik $L$ dan $M$ sehingga terlukislah segitiga KLM

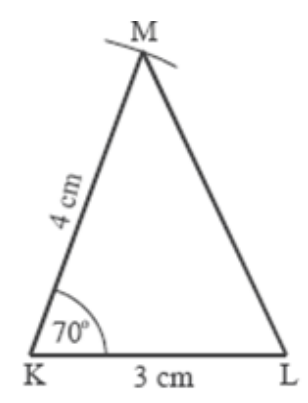

$\star \quad$ Melukis Segitiga jika Diketahui Dua Sisi dan Satu Sudut di Hadapan Salah Satu dari Kedua Sisi Tersebut

Misalkan kita akan melukis segitigaRST apabila diketahui panjang RS = 5 $\mathrm{cm}$, sudut TRS $=450$, dan sudut TSR $=650$.

Langkah-langkahnya sebagai berikut.

1) Buatlah ruas garis $R S$ dengan panjang $5 \mathrm{~cm}$.

2) Dari titik $R$, buatlah sudut yang besarnya 45 o dengan menggunakan busur derajat.

3) Kemudian dari titik $S$, buatlah sudut yang besarnya 650 sehingga berpotongan dititik $\mathrm{T}$.

4) segitiga RST adalah segitiga yang dimaksud 


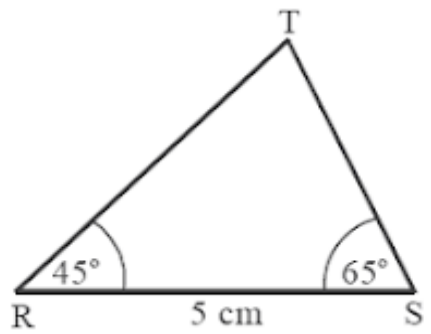

C. Bangun Ruang Limas Segilima

1. Pengertian Limas Segilima

Limas segilima merupakan jenis limas yang mempunyai bentuk alas bangun datar segi lima baik itu segi lima teratur maupun segi lima sembarang.

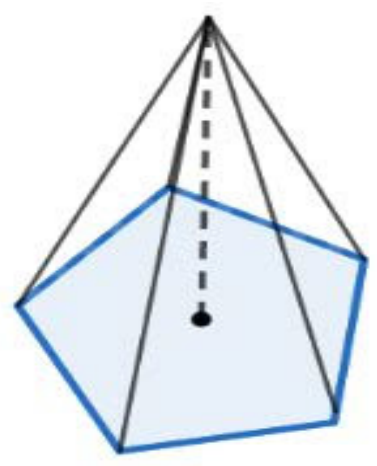

Bangun limas segi lima memiliki enam sisi. Enam sisi tersebut meliputi satu sisi alas dan lima sisi tegak limas. Sisi alas berupa bangun datar segi lima dan sisi tegak berupa bangun segitiga. Bangun limas segi lima memiliki lima bidang diagonal yang berbentuk segitiga.

2. Jaring-Jaring Limas Segi Lima

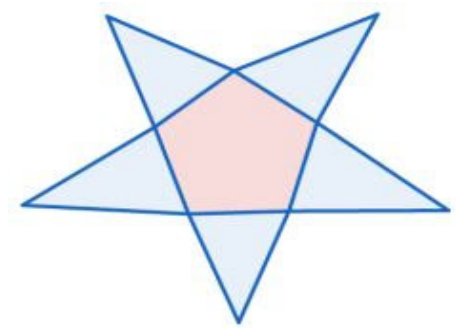


Pada jaring-jaring tersebut, terlihat bahwa bangun limas segi lima memiliki enam sisi.

Sisi alas berupa segi lima dan lima sisi lainnya merupakan sisi tegak limas yang berbentuk segitiga. Kelima tegak limas bertemu di satu titik yaitu titik puncak limas.

3. Ciri-ciri Limas Segilima

1) Bidang atas merupakan sebuah titik yang berbentuk lancip dan menggabungkan banyak sisi.

2) Pada bagian bawah ini terdapat bangun datar yang memiliki bentuk segi lima.

3) Bidang tegak pada bangun ruang ini berbentuk segitiga yang memiliki ukuran sama.

4) Bangun ruang ini memiliki 6 titik sudut, 6 bidang sisi, 5 sisi tegak, dan 5 rusuk alas. Untuk mendapatkan penjelasan yang lebih rinci perhatikan gambar limas segi lima.

4. Rumus Volume Limas Segi Lima

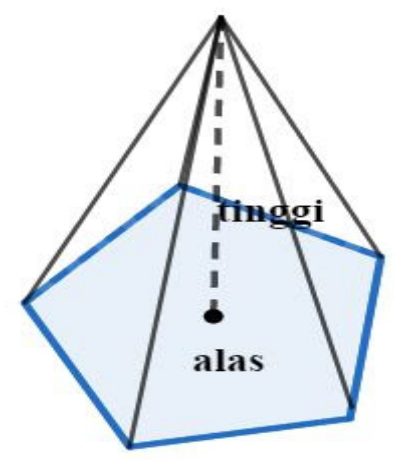

Volume Limas Segi Lima

$V=1 / 3 \times$ La $x t$

Keterangan:

- $\quad \mathrm{V}$ : volume limas segi lima

- La : Luas alas limas 
- $\mathrm{t}$ : tinggi limas segi lima

Contoh :

Sebuah limas segi lima memiliki tinggi 60 centimeter dan luas alas dengan 200 centimeter kubik. Hitunglah volume dari limas dengan menggunakan rumus yang telah ditentukan.

Jawab :

Diketahui tinggi bangun ruang limas ini adalah $60 \mathrm{~cm}$ dan luas alas 200 centimeter kubik. Kita aka menggunakan rumus volume dari limas segi lima. Sehingga menjadi:

$V=1 / 3 \times$ luas alas $\times$ tinggi $=1 / 3 \times 200 \times 60=4000 \mathrm{~cm}^{3}$.

Jadi volume dari bangun ruang limas segi lima ini adalah $4000 \mathrm{~cm}^{3}$.

BAB III

PENUTUP

A. Kesimpulan

Sistem bilangan desimal disusun dari 10 angka atau lambang. Dengan menggunakan lambang-lambang tersebut sebagai digit pada sebuah bilangan, kita dapat mengekspresikan suatu kuantitas. Kesepuluh lambang tersebut adalah: $D=\{0,1,2,3,4,5,6,7,8,9\}$

Pada operasi hitung pecahan desimal untuk Penjumlahan dan Pengurangan sebaiknya kita gunakan metode Penjumlahan/Pengurangan susun dan caranya sama dengan Penjumlahan/Pengurangan Bilangan Bulat, yaitu dengan meluruskan angka satuannya. Yang mesti kita cermati adalah bahwa angka yang tepat di depan koma itu adalah angka satuan, maka akan lebih mudah diingat bila bahasanya kita ubah menjadi "yang diluruskan adalahkoma" 
Yang sangat perlu diperhatikan pada Operasi Perkalian dan Pembagian susun adalah "Jumlah Angka Dibelakang Koma".

Segitiga adalah bangun datar yang dibatasi oleh tiga buah sisi dan mempunyai tiga buah titik sudut.

- Terdapat berbagai cara untuk mendefinisikan segitiga.

- Terdapat berbagai macam jenis segitiga.

- Pada setiap segitiga ABC berlaku ketidaksamaan segitiga, yaitu jumlah panjang dua sisi segitiga selalu lebih panjang dari sisi yang lain.

- Jumlah besar sudut suatu segitiga adalah $180^{\circ}$.

- Pada dasarnya suatu segitiga dapat dianggap sebagai suatu segiempat yang dibagi menurut salah satu diagonalnya.

- Konsep segitiga adalah suatu konsep yang merupakan dasar untuk menguasai konsep konsep bangun datar lain bahkan untuk membantu mengkaji konsep bangun ruang khususnya bangun ruang sisi datar.

Bangun limas segi lima memiliki enam sisi. Enam sisi tersebut meliputi satu sisi alas dan lima sisi tegak limas. Sisi alas berupa bangun datar segi lima dan sisi tegak berupa bangun segitiga.

Rumus volume limas segi lima : $V=1 / 3$ x La xt.

B. Saran

Dengan selesainya makalah ini, penyusun berharap kepada para pembaca agar dapat memberi masukan baik berupa kritik atau saran yang sifatnya membangun agar pada perbaikan makalah ini, pembaca mendapat manfaat yang lebih daripada sebelumnya. 
DAFTAR PUSTAKA

Jusmawati,S.Pd., M.Pd.

Matematika dasar. Makassar: 2014

Khalilah, Royatul. (2013). Desimal dan Bilangan Real. [Online]. Tersedia:

http://royatulkhalilah14.blogspot.co.id/2013/11/desi

mal-dan-bilangan-real.html?m=1 [diakses 2 Mei 2018

http://dw1pu2wa.blogspot.co.id/2013/11/prisma-dan-limas.html 
W Edit dengan WPS Office 